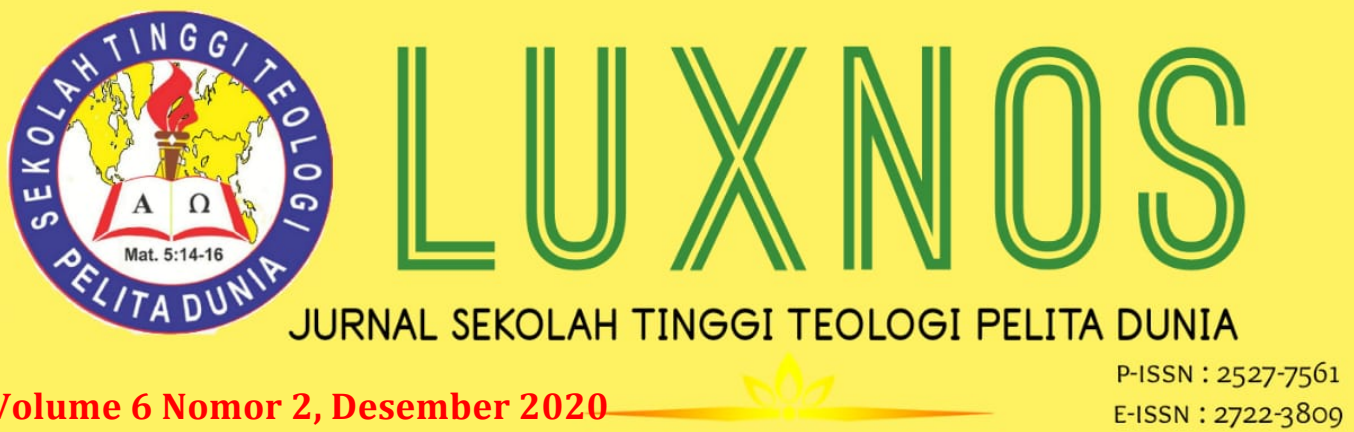

\title{
Pentingnya Pelayanan Pastoral Terhadap Korban LGBT
}

\author{
Sri Dwi Harti \\ Sekolah Tinggi Teologi Pelita Dunia Tangerang, \\ dwiharti@hotmail.com
}

\begin{abstract}
This research is about LGBT issues and how the Church responds and handles the victims or perpetrators of LGBT. This research tries to analyze and provide solutions to the church regarding effective pastoral care for LGBT groups. By using a qualitative research approach or method that focuses more on literature review, this study concludes that through the guiding function, the function of improving relations, and the function of healing, it should be executed properly and correctly it will be very effective in dealing with victims and perpetrators of LGBT.
\end{abstract}

Keywords: LGBT, Pastoral Ministry, Pastoral.

\begin{abstract}
Abstrak: Penelitian ini seputar isu LGBT dan bagaimana respons serta penanganan yang dilakukan oleh Gereja terhadap para korban atau pelaku LGBT. Pada penelitian ini mencoba menganalisis dan memberikan solusi kepada gereja perihal pelayanan pastoral yang efektif kepada kelompok LGBT. Dengan menggunakan pendekatan atau metode penelitian kualitatif yang lebih menitikberatkan pada kajian pustaka, maka penelitian ini menyimpulkan bahwa melalui fungsi membimbing, fungsi memperbaiki hubungan, dan fungsi menyembuhkan, maka apabila dijalankan dengan baik dan benar akan sangat efektif menangani korban maupun pelaku LGBT.
\end{abstract}

Kata Kunci: LGBT, Pelayanan Pastoral, Penggembalaan.

\section{Pendahuluan}

LGBT merupakan akronim dari lesbian, gay, biseksual dan transgender. Ungkapan ini sebenarnya bukan ungkapan yang asing, oleh karena sudah sering didengarkan dan dibaca melalui pemberitaan media elektronik, termasuk TV, Radio hingga media cetak, tabloid dan koran-koran. Dalam penelitian dan tulisan ini, istilah LGBT diasosiasikan kepada kelompok yang memiliki orientasi seks yang berbeda atau tidak sama dengan manusia normal pada umumnya. Misalnya: perempuan dengan perempuan atau laki-laki dengan laki-laki. 
Apabila mengacu kepada ajaran Alkitab, maka tentunya orientasi seks seperti ini sudah melenceng atau sudah tidak sejalan dengan apa yang dikehendaki oleh Allah. Karena dalam Kejadian 2:22-25, sudah dengan jelas ditegaskan bahwa Allah menciptakan laki-laki dan perempuan untuk selanjutnya mereka membentuk sebuah keluarga dan saling mencintai untuk hidup dalam kasih dan memiliki keturunan.

Menurut Tafsir Alkitab Perjanjian Lama ketika mengomentari perikop Kejadian 2:22-25 mengatakan, "Wanita merupakan satu-satunya penolong yang sepadan bagi laki-laki". ${ }^{1}$ Inilah pasangan yang ideal yang diciptakan oleh Allah. Sekalipun kemudian berubah dan menjadi rusak setelah manusia jatuh ke dalam dosa. Manusia banyak melakukan dosa di hadapan Tuhan. Termasuk dosa seksual dengan melakukan penyimpangan-penyimpangan seperti yang dilakukan oleh kelompok LGBT.

Dosa penyimpangan seksual yang identik dengan LGBT secara tersurat dicatat dalam Kejadian 19 di kota Sodom dan Gomora. "Istilah ini telah digunakan sebagai kata yang mengacu kepada dosa dan penyelewengan seksual. Kisah tersebut telah membentuk kata-kata baru dalam berbagai bahasa di seluruh dunia, termasuk perkataan dalam bahasa Melayu dan bahasa Indonesia yakni "menyodomi", suatu istilah yang digunakan untuk menjelaskan hubungan anal seks, dan juga hubungan seks seperti binatang". ${ }^{2}$ Para penduduk pria Sodom dan Gomora ingin ramai-ramai memperkosa kedua malaikat (yang tampak sebagai pria). Pada waktu bersamaan, secara alkitabiah kita tidak bisa menunjuk hanya kepada dosa homoseksualitas sebagai satu-satunya alasan Allah menghancurkan Sodom dan Gomora. ${ }^{3}$

Berdasarkan beberapa pendapat di atas telah memberikan sebuah indikasi yang cukup kuat betapa penyimpangan seksual yang dilakukan oleh korban LGBT tidak sejalan dengan ajaran Alkitab. Dengan demikian, perlu bagi setiap orang Kristen memiliki pemahaman yang benar dan tindakan yang tepat untuk menghadapi dan menangani para pelaku atau lebih tepatnya korban LGBT. Supaya dapat menjalankan fungsi dan tugas yang tepat, yakni: tetap tidak kompromi dengan dosa namun tetap merangkul dengan kasih Kristus.

Awal tahun 2020, terkuak sebuah kasus LGBT yang membuat mata terbelalak. Di mana ada seorang WNI, bernama Reinhard Sinaga, yang sedang melanjutkan studi di Manchester, Inggris, divonis bersalah dengan hukuman

\footnotetext{
${ }^{1}$ Robert J. Karris Dianne Bergant, ed., Tafsir Alkitab Perjanjian Lama (Yogyakarta: Kanisius, 2002), 38-39.

2“Https://Id.Wikipedia.Org/Wiki/Sodom_dan_Gomora\#: :Text=Sodom\%20dan\%20Am ora\%20adalah\%20dua,Berasal\%20dari\%20TUHAN\%2C\%20dari\%20langit."

3 "Https://Www.Gotquestions.Org/Indonesia/Sodom-Gomora.Html."
} 
penjara seumur hidup oleh Pengadilan Inggris karena telah memperkosa ratusan pria di sana. Akan tetapi, pengakuan mencengangkan yang disampaikan oleh ibu Reinhard. Seperti yang dimuat Kompas.com, "Ibu Reynhard menggambarkannya sebagai "anak yang baik, rajin beribadah, rajin ke gereja". ${ }^{4}$

Bagaimana mungkin seorang yang begitu rajin beribadah dapat terjebak dan terjerumus dalam kejahatan seksual demikian? Namun, dari fakta ini menunjukkan bahwa ada hal yang perlu dikoreksi dan diperbaiki dalam pelayanan di gereja. Supaya di masa depan tidak ada lagi kasus-kasus LGBT yang mencengangkan seperti ini. Gereja harus memiliki pendekatan dan metode pastoral yang efektif guna menyelesaikan persoalan seperti ini hingga tuntas.

Bahkan realitas LGBT di konteks Indonesia saat ini juga menimbulkan pro dan kontra. Seperti yang dikemukakan oleh Manasye Indra Kusuma, "visibilitas kaum LGBT di Indonesia pada saat ini sudah mulai tampak lebih jelas dibandingkan pada waktu-waktu terdahulu. Baik mereka yang mengungkapkan diri sebagai homoseksual, atau juga gerakan-gerakan yang terus terang menerima eksistensi mereka, mulai berani menunjukkan dirinya. Keberanian untuk "keluar" tersebut didukung dengan hasil riset, perkembangan ilmu pengetahuan yang juga terwujud dalam kebijakan beberapa lembaga yang menghapus homoseksualitas dari kategori gangguan kejiwaan. Selain itu, pengamatan akan banyaknya bentuk-bentuk penolakan masyarakat yang mengungkung dan berakibat buruk pada kaum ini juga mendorong kepedulian dari para pemerhatinya". ${ }^{5}$

Pada penelitian ini, kelompok ini dikategorikan sebagai korban. Mengapa? Karena mereka adalah orang-orang yang harus dan patut diselamatkan dan dipulihkan. Itulah sebabnya dalam penelitian ini lebih menekankan kepada peran pelayanan pastoral bukan pada LGBT-nya. Supaya penelitian ini dapat menjadi acuan, pedoman hingga materi bagi setiap gereja dalam menghadapi dan menangani setiap korban LGBT dalam gereja. Dengan demikian, mengoreksi setiap tindakan yang keliru yang terlanjur dilakukan oleh gereja yakni membiarkan atau mengucilkan mereka tanpa memberikan sebuah pelayanan pastoral yang bertujuan untuk mengembalikan mereka pada kehidupan yang dikehendaki oleh Allah.

4 "Https://Internasional.Kompas.Com/Read/2020/01/07/12472331/Di-Mata-IbuReynhard-Sinaga-Adalah-Anak-Yang-Baik-Dan-Rajin-Beribadah?Page=all.," Kompas. Com., 2020.

${ }^{5}$ Manasye Indra Kusuma and Sains Teologi, "STUDI SOSIO-HISTORIS TERHADAP KISAH PENCIPTAAN MANUSIA DALAM KEJADIAN 1: 27-28 DAN KEBERADAAN KAUM LGBT DI INDONESIA" (n.d.). 


\section{Metode Penelitian}

Penelitian ini menggunakan pendekatan atau metode kualitatif. Metode ini dipilih dan digunakan karena memang fokus dan tujuan penelitian ini adalah untuk memperoleh data kualitatif tentang peran pastoral terhadap korban LGBT. Dengan demikian penelitian ini dapat menjadi masukan, materi, bahkan dasar bertindak setiap pelayan Tuhan dalam gereja untuk menghadapi dan melayani setiap korban LGBT. Melalui pendekatan kualitatif, peneliti menggunakan kajian pustaka. Di mana setiap data yang diperoleh dari pustaka akan dielaborasi menjadi sebuah data dan kesimpulan kualitatif untuk tema ini. Menurut Adi Putra, "Semua kajian kualitatif di dalam penelitian ini bertumpu pada kajian literatur melalui sumber-sumber primer seperti buku, artikel jurnal, ensiklopedia dan majalah". ${ }^{6}$

\section{Hasil Dan Pembahasan}

\section{A. LGBT dalam Perspektif Iman Kristen}

Setiap orang yang terlibat atau mempunyai orientasi seksual yang tergolong ke dalam LGBT dapat dipastikan telah melakukan pelanggaran terhadap hukum Allah. Seperti yang telah dikemukakan di atas, bahwa sejak semula manusia diciptakan Tuhan untuk masing-masing berpasang-pasangan antara laki-laki dan perempuan (Kej. 2:18-25). Bahkan Alkitab dengan jelas dan tegas juga menyebutkan bahwa setiap manusia diciptakan segambar dan serupa dengan Allah (Kej. 1:27-28).

Menurut Anita Mauboy dan Sjanette Eveline, "Pernikahan adalah lembaga pertama yang ditetapkan Allah sendiri. Dalam (Kej 2: 18-25), Alkitab dengan tegas menyatakan bahwa penetapan dan pembentukan lembaga pernikahan telah diselenggarakan sebelum dunia jatuh ke dalam dosa. Ketika Allah menciptakan manusia, Ia menciptakan pria dan wanita dan melaluinya Allah merancang lembaga pernikahan".7 Artinya, bahwa sejak semula Tuhan Allah menghendaki setiap manusia membentuk keluarga terdiri dari laki-laki dan perempuan. Bahkan kembali ditegaskan oleh Yesus dalam Markus 10:6-8 bahwa sejak semula Tuhan Allah menciptakan laki-laki dan perempuan.

Selain itu, manusia juga menyandang status sebagai gambar dan rupa Allah. Di mana setiap manusia wajib menjalankan kehendak Allah di dunia dan

${ }^{6}$ Adi. Putra, “Kajian Biblika Terhadap Makna "Ta Stigmata Tou Iesou” Dalam Galatia 6:17,'” SUNDERMANN: Jurnal Ilmiah Teologi, Pendidikan, Sains, Humaniora dan Kebudayaan 13, no. 1, no. March, 2020 (2020).

7 Anita Mauboy and Sjanette Eveline, "Pemahaman Pernikahan Kudus Suku Dawan Ditinjau Dari Kejadian 1: 27-28,” Journal KERUSSO 4, no. 2 (2019): 23-32. 
senantiasa merefleksikan kemuliaan Allah kepada seluruh dunia, termasuk dalam hal pernikahan yang dikehendaki Allah.

Dalam Kejadian 19:4-5 juga memberikan penegasan betapa Alkitab tidak setuju kepada LGBT. Konteks dalam ayat ini adalah bahwa masyarakat kota Sodom mereka menganut paham gay atau seks dengan sesama jenis. Hal itu terbukti saat malaikat yang datang di kota Sodom mereka hendak melakukan hubungan seks sesama jenis dengan para malaikat. Karena itulah Tuhan memusnahkan kota Sodom dan Gomora.

Selanjutnya Imamat 18:22, juga memberikan indikasi bagaimana Allah tidak setuju dengan praktik LGBT. Bahkan dalam Imamat 20:13 ditegaskan Tuhan akan menghukum mati bagi para pelaku LGBT. Oleh karena itu dalam Roma 1:25-27 ditegaskan bahwa bagi pelaku dan korban LGBT dianggap melakukan kejahatan yang besar karena telah melupakan penciptanya dan terjebak dalam nafsu dunia yang sesat dan bejat.

Penjelasan dalam Yudas 1:5-7 juga memberikan sebuah penjelasan yang tegas perihal dosa LGBT yang bertentangan dengan ajaran Alkitab. David H. Wheaton mengatakan, "Melakukan percabulan dan mengejar kepuasan-kepuasan yang tidak wajar, secara harfiah berarti berleluasa dalam kebejatan moral seksual dan mengejar daging-daging yang aneh. Hal itu mungkin berkaitan dengan acuan ayat 6 tentang Kejadian 6, mengingat dosa-dosa Sodom (Kej. 18:20) mencapai puncaknya ketika mereka berusaha memaksakan persetubuhan dengan dua malaikat yang diutus kepada Lot (Kej. 19:15)”." Selanjutnya ditambahkan oleh Wheaton, "Siksaan api kekal adalah apa yang diajarkan Yesus dalam Matius 18:8; 25:41; dan Markus 9:48”. ${ }^{9}$ Artinya mereka yang terjerumus ke dalam dosa LGBT akan dihukum dengan siksaan dalam api yang kekal.

Berdasarkan pandangan Iman Kristen yang didasarkan pada ajaran Alkitab inilah, maka perlu sekali bagi gereja untuk memberikan pelayanan pastoral yang efektif bagi para korban LGBT, bahkan termasuk melakukan tindakan preventif. Namun sebelum sampai ke sana, maka akan dibahas dulu fungsi pelayanan pastoral dalam gereja.

\section{B. Fungsi Pelayanan Pastoral}

Gereja menjadikan pelayanan pastoral sebagai pelayanan yang penting. Oleh karena itu, tidak keliru apabila dikatakan bahwa pelayanan pastoral merupakan pelayanan yang menempati ruang yang begitu luas dan penting

\footnotetext{
${ }^{8}$ G.J. Wenham. D.A. Carson, R.T. France, J.A. Motyer, ed., Tafsiran Alkitab Abad Ke-21 (Matius-Wahyu) (Jakarta: YKBK/OMF, 2017), 715.

9 Ibid.
} 
dalam pelayanan gerejawi. Menurut Grain Dobbins dalam bukunya John E. Ingouf, "berdasarkan etimologi, kata pastoral itu, kata dasarnya pastor (Latin) dan bahasa Yunaninya poimen yang berarti Gembala. Jadi pastoral dapat di sebut juga pastoralia atau poimenikh atau penggembalaan".10 Kemudian M. BonsStorm mengatakan, "Pastoral dilihat dari kata kiasan, poimen (Yunani) menggambarkan orang yang bertindak sebagai gembala jemaat. Hal ini juga memberi makna sebagai pemimpin dan penjaga kawanan domba yaitu jemaat (Kisah Para Rasul 20:18)".11

Dengan demikian, dapat dilihat bahwa pelayanan pastoral dapat juga disebut pelayanan penggembalaan yang dilakukan oleh gembala dalam jemaat yang bertujuan untuk membimbing dan mendidik jemaat tentang Firman Tuhan sehingga jemaat senantiasa berjalan pada koridor yang benar. Pendapat ini dipertegas oleh Rahel Jum Juld dan I Ketut Enoh, "Tugas dan tanggung jawab seorang gembala adalah menjaga, membimbing, memelihara, merawat, menuntun, mengajak, mendisiplinkan dan menghibur domba-domba Allah yaitu jemaat Tuhan".12 Berdasarkan pendapat itu, maka pelayanan pastoral begitu penting dalam pelayanan gerejawi.

Berdasarkan apa yang dikemukakan oleh Aart van Beek bahwa ada beberapa fungsi dalam pelayanan pastoral, yakni: fungsi membimbing, fungsi mendamaikan/memperbaiki hubungan, fungsi menopang/menyokong, fungsi menyembuhkan, fungsi mengasuh, dan fungsi mengutuhkan. ${ }^{13}$ Berikut akan dijelaskan secara singkat dan gamblang perihal masing-masing fungsi ini.

Fungsi membimbing berarti fungsi yang dijalankan untuk membawa kembali setiap jemaat yang tersesat atau memerlukan panduan untuk kembali kepada jalan yang benar. Seperti yang juga ditegaskan oleh Beek, "Fungsi membimbing penting dalam kegiatan menolong dan mendampingi seseorang". ${ }^{4}$ Berdasarkan penjelasan di atas, maka dapat dikatakan bahwa fungsi membimbing memiliki tempat yang penting dalam pelayanan pastoral.

Fungsi mendamaikan/memperbaiki hubungan berarti pelayanan pastoral memiliki peran untuk memperbaiki hubungan yang retak atau rusak antara jemaat, baik dalam relasi sosial dalam masyarakat, dalam keluarga hingga problem hubungan yang lain yang memerlukan pendampingan pastoral guna memperbaiki hubungan yang telah rusak. 1988), 14

10 John E. Ingouf, Seklumit Tentang Gembala Sidang (Bandung: Lembaga Literatur Baptis,

${ }^{11}$ M. Bons-Storm, Apakah Penggembalaan Itu? (Jakarta: BPK Gunung Mulia, 1988), 19.

12 Rahel Jum Juld and I Ketut Enoh, "Okultisme Dalam Pelayanan Pastoral," Jurnal Jaffray 11, no. 2 (2013): 165-190.

13 Aart van Beek, Pendampingan Pastoral (Jakarta: BPK Gunung Mulia, 2007), 13-17.

14 Ibid., 13. 
Fungsi menopang/menyokong adalah fungsi pastoral yang dilakukan oleh gereja untuk menyokong atau membantu jemaat yang sedang mengalami krisis ekonomi. Pendampingan ini juga wajib dilakukan oleh gereja oleh karena gereja memang berfungsi untuk memperbaiki ekonomi jemaat, sehingga jemaat melihat dalam gereja ada orang-orang yang senantiasa siap membantunya.

Fungsi menyembuhkan juga merupakan fungsi pelayanan pastoral yang signifikan. Seperti yang dikemukakan oleh Beek, "Fungsi menyembuhkan ini penting dalam arti bahwa melalui pendampingan yang berisi kasih saying, rela mendengarkan segala keluhan batin, dan kepedulian yang tinggi akan membuat seseorang yang menderita mengalami rasa aman dan kelegaan sebagai pintu masuk ke arah penyembuhan yang sebenarnya". ${ }^{15}$

Artinya pelayanan pastoral memang tidak secara langsung menjadi obat yang menyembuhkan penyakit. Namun melalui pendampingan pastoral yang dilakukan, maka akan memberikan sukacita dan pengharapan kepada jemaat yang menderita sakit dan selanjutnya akan memberikannya hati yang gembira dan secara psikologis dapat berdampak kepada kesembuhannya. Seperti yang dikemukakan oleh Firman Tuhan, "Hati yang gembira adalah obat".

Fungsi mengasuh berarti melalui pelayanan pastoral, setiap jemaat dapat dibimbing atau didampingi untuk senantiasa dapat bertumbuh dengan baik dan normal dalam hal emosional, cara berpikir, motivasi dan kemauan, tingkah laku, kehidupan rohani serta interaksi dan sebagainya.

Fungsi mengutuhkan merupakan pendampingan yang dilakukan dengan senantiasa memperhatikan kehidupan manusia secara utuh, yakni: fisik, sosial, mental, dan spiritual. Pendampingan ini memang identik dengan pendampingan sebelumnya, namun pendampingan yang jenis ini juga dapat dilakukan guna mencegah terjadinya keretakan hubungan antara jemaat. Sehingga pendampingan ini lebih bersifat pendampingan preventif.

Dengan demikian, dapat dilihat dan dipahami beberapa fungsi dari pelayanan pastoral yang nantinya akan diterapkan kepada korban LGBT.

\section{Pentingnya Pelayanan Pastoral terhadap Korban dan Pelaku LGBT}

Berdasarkan uraian sebelumnya, di mana dikemukakan ada beberapa fungsi dari pelayanan pastoral, yakni: fungsi membimbing, fungsi mendamaikan/memperbaiki hubungan, fungsi menopang/menyokong, fungsi menyembuhkan, fungsi mengasuh, dan fungsi mengutuhkan.

Dari beberapa fungsi di atas, terlihat ada beberapa fungsi yang memang sangat relevan untuk menghadapi dan membimbing korban dan pelaku LGBT.

15 Ibid., 14. 
Misalnya: fungsi membimbing, fungsi memperbaiki hubungan, dan fungsi menyembuhkan.

Membimbing berarti menuntun dan mengarahkan setiap korban dan pelaku LGBT untuk mengerti dan memahami ajaran Firman Tuhan dengan benar. Setiap pelayan perlu menyampaikan kepada mereka betapa Allah tidak suka dengan LGBT. Selanjutnya menyampaikan kepada mereka bahwa penyimpangan seksual dalam LGBT adalah sebuah dosa dan kejahatan yang dimurkai Allah. Sehingga mereka dapat menyadari akan hal tersebut. Tidak sampai di situ, selanjutnya pelayan juga harus membimbing mereka hingga sampai kepada titik mereka mengakui kesalahan itu dan mau berkomitmen untuk memperbaiki diri dan memperbarui kehidupan dengan orientasi seksual yang benar seturut ajaran Alkitab.

Memperbaiki hubungan berarti mengadakan rekonsiliasi. Dalam konteks ini yang direkonsiliasi adalah hubungan si korban dengan Tuhan dan juga rekonsiliasi dengan diri sendiri dan sesama. Biasanya ketiga relasi ini yang menjadi persoalan utama setiap korban dan pelaku LGBT. Rekonsiliasi dengan Tuhan berarti melakukan tranformasi hidup dengan sikap dan tindakan yang selalu selaras dengan ajaran Alkitab. Kehidupan yang sebelumnya selalu melakukan dosa dan lebih senang berbuat dosa dari pada melakukan kehendak Tuhan. Namun, apabila telah melakukan rekonsiliasi dengan Tuhan, maka setiap perbuatan-perbuatan yang identik dengan dosa harus ditinggalkan. Dalam hal ini adalah LGBT. Di mana setiap orang yang telah melakukan rekonsiliasi dengan Tuhan tidak lagi melakukan praktik LGBT.

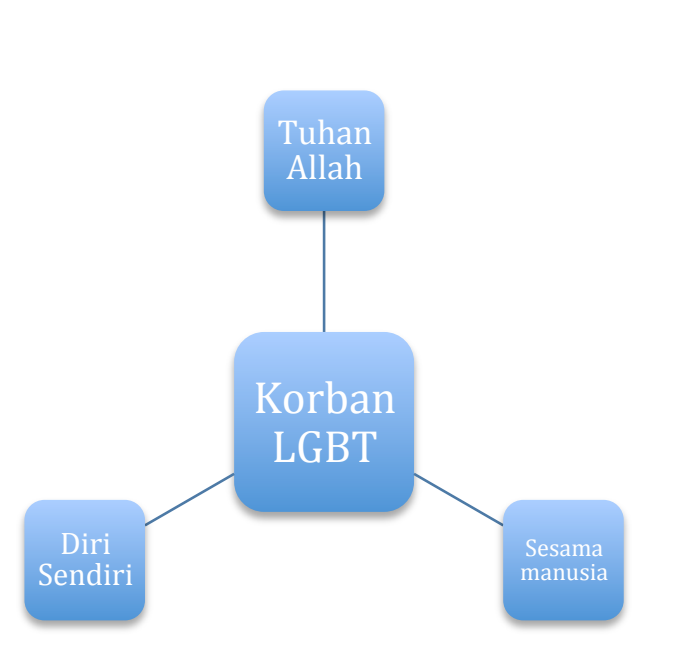

Rekonsiliasi dengan diri
sendiri adalah bagaimana setiap
korban dan pelaku LGBT dapat
menerima diri sendiri sebagai
ciptaan Tuhan yang paling mulia
karena diciptakan segambar dan
serupa dengan Allah. Dari sini
mereka akan dapat menerima dan
memaafkan diri mereka yang telah
banyak melakukan kesalahan karena
telah terjebak dalam dosa LGBT. Hal
ini penting supaya dapat memulihkan kepercayaan dirinya. Karena kepercayaan diri ini akan sangat diperlukan olehnya untuk bangkit dari keterpurukan dan menata kembali kehidupan baru bersama Kristus.

Rekonsiliasi yang terakhir adalah rekonsiliasi dengan sesama. Hal ini juga merupakan sesuatu yang sangat diperlukan oleh setiap korban dan pelaku LGBT. 
Supaya mereka dapat diterima kembali ke dalam kehidupan masyarakat sebagai manusia yang normal.

Menyembuhkan berarti memulihkan dan mentahirkan dari sesuatu penyakit yang membuatnya semakin jauh dari kehidupan yang mempermuliakan Allah. Pelaku dan korban LGBT sangat perlu kesembuhan, agar dapat terbebas dari dosa dan pengaruh LGBT yang terus-menerus menggerogoti dan merusak kehidupan mereka. Bukan hanya kehidupan jasmani melainkan juga kehidupan rohani. Oleh karena banyak juga pelaku dan korban LGBT yang akhirnya mengakhiri hidup dengan sakit yang parah misalnya: AIDS, dll.

Dengan demikian, pentingnya pelayanan pastoral bagi para pelaku dan korban LGBT, supaya mereka dapat diselamatkan dan dikembalikan kepada kehidupan yang normal. Tidak ada yang mustahil, karena kuasa Roh Kudus mampu untuk memulihkan dan menyembuhkan setiap korban LGBT. Tugas dan tanggung jawab gereja adalah menjadi instrument di tangan Tuhan untuk menyembuhkan dan membimbing mereka kembali kepada Kristus melalui pelayanan pastoral.

\section{Kesimpulan}

Setelah meneliti dan memberikan penjabaran yang rinci dan sistematis terhadap pentingnya pelayanan pastoral bagi korban LGBT, maka berikut ini akan dikemukakan beberapa kesimpulan.

Pertama, berdasarkan pembahasan dalam penelitian ini, maka dapat dijumpai bahwa LGBT merupakan sebuah dosa dan kejahatan. Oleh karena LGBT adalah tindakan dan perilaku yang tidak alkitabiah bahkan berlawanan dengan ajaran Alkitab.

Kedua, gereja bertanggung jawab untuk melayani dan melakukan pendekatan pastoral kepada setiap pelaku dan korban LGBT. Gereja tidak boleh melakukan pembiaran. Bahkan apabila dimungkinkan, maka gereja juga dapat melakukan tindakan preventif.

Ketiga, fungsi pelayanan pastoral dapat dibagi ke dalam beberapa fungsi, yakni: fungsi membimbing, fungsi mendamaikan/memperbaiki hubungan, fungsi menopang/menyokong, fungsi menyembuhkan, fungsi mengasuh, dan fungsi mengutuhkan.

Keempat, ada beberapa fungsi dari pelayanan pastoral yang sangat relevan untuk menghadapi dan membimbing korban dan pelaku LGBT. Misalnya: fungsi membimbing, fungsi memperbaiki hubungan, dan fungsi menyembuhkan.

Kelima, fungsi membimbing berarti menuntun dan mengarahkan setiap korban dan pelaku LGBT untuk mengerti dan memahami ajaran Firman Tuhan dengan benar. Fungsi memperbaiki hubungan berarti mengadakan rekonsiliasi. 
Dalam konteks ini yang direkonsiliasi adalah hubungan si korban dengan Tuhan dan juga rekonsiliasi dengan diri sendiri dan sesama. Biasanya ketiga relasi ini yang menjadi persoalan utama setiap korban dan pelaku LGBT. Terakhir adalah fungsi menyembuhkan berarti memulihkan dan mentahirkan dari sesuatu penyakit yang membuatnya semakin jauh dari kehidupan yang mempermuliakan Allah. Pelaku dan korban LGBT sangat perlu kesembuhan.

\section{Referensi}

Beek, Aart van. Pendampingan Pastoral. Jakarta: BPK Gunung Mulia, 2007.

D.A. Carson, R.T. France, J.A. Motyer, dan G.J. Wenham., ed. Tafsiran Alkitab Abad Ke-21 (Matius-Wahyu). Jakarta: YKBK/OMF, 2017.

Dianne Bergant, Robert J. Karris, ed. Tafsir Alkitab Perjanjian Lama. Yogyakarta: Kanisius, 2002.

Ingouf, John E. Seklumit Tentang Gembala Sidang. Bandung: Lembaga Literatur Baptis, 1988.

Juld, Rahel Jum, and I Ketut Enoh. "Okultisme Dalam Pelayanan Pastoral." Jurnal Jaffray 11, no. 2 (2013): 165-190.

Kusuma, Manasye Indra, and Sains Teologi. "STUDI SOSIO-HISTORIS TERHADAP KISAH PENCIPTAAN MANUSIA DALAM KEJADIAN 1: 27-28 DAN KEBERADAAN KAUM LGBT DI INDONESIA" (n.d.).

M. Bons-Storm. Apakah Penggembalaan Itu? Jakarta: BPK Gunung Mulia, 1988. Mauboy, Anita, and Sjanette Eveline. "Pemahaman Pernikahan Kudus Suku Dawan Ditinjau Dari Kejadian 1: 27-28." Journal KERUSSO 4, no. 2 (2019): 23-32.

Putra, Adi. “Kajian Biblika Terhadap Makna "Ta Stigmata Tou Iesou” Dalam Galatia 6:17.'" SUNDERMANN: Jurnal Ilmiah Teologi, Pendidikan, Sains, Humaniora dan Kebudayaan 13, no. 1, no. March, 2020 (2020).

"Https://Id.Wikipedia.Org/Wiki/Sodom_dan_Gomora\#: :Text=Sodom\%20dan \%20Amora\%20adalah\%20dua,Berasal\%20dari\%20TUHAN\%2C\%20dari\% 20langit."

"Https://Internasional.Kompas.Com/Read/2020/01/07/12472331/Di-MataIbu-Reynhard-Sinaga-Adalah-Anak-Yang-Baik-Dan-RajinBeribadah?Page=all." Kompas. Com., 2020.

"Https://Www.Gotquestions.Org/Indonesia/Sodom-Gomora.Html." 